\title{
InNocence is Not Enough: The Public Life of DEATH ROW EXONERATIONS
}

\section{Austin Sarat*, Natalie Morgan**, Willa Grimes***, Obed Narcisse ${ }^{* * * *}$, Jeremy Thomas*****}

\begin{abstract}
Miscarriages of justice and wrongful convictions are a pervasive reality in America's criminal justice system. In this paper we examine news coverage of miscarriages of justice in the death penalty system and the release of death row inmates to understand what we call the public life of exonerations. We examine the way newspapers tell the story of exonerations and the various tilts and tendencies that characterize their presentations. We focus on the five states which, from 1972-2019, had ten or more exonerations. During that period, they were Florida, Illinois, Texas, Louisiana, and Oklahoma. We conclude that the public discourse surrounding exoneration, while providing evidence of the death penalty system's most consequential flaws, serves as much to preserve that system as to challenge it.
\end{abstract}

\section{KEYWORDS}

Miscarriages of Justice, Exonerations, Death Penalty, News Coverage

\section{CONTENTS}

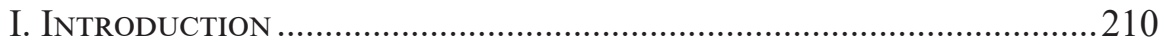

II. The LANGUAGE OF EXONERATION ......................................................219

III. INNOCENCE: AN UNSETTLED QueSTION ...........................................222

IV. What Difference Does DNA Make?..............................................225

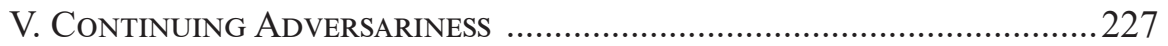

VI. Attributing Blame for MisCARriages of Justice ........................228

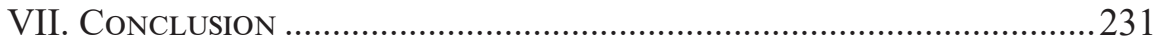

* Professor of Jurisprudence and Political Science, Amherst College, Amherst, Mass.

** Class of 2021, Amherst College Amherst, Mass.

*** Class of 2021, Amherst College, Amherst, Mass.

${ }^{* * * *}$ Class of 2021, Amherst College, Amherst, Mass.

${ }^{* * * * * *}$ LClass of 2021, Amherst College, Amherst, Mass.

\# We gratefully acknowledge the support for this project provided by Amherst College and the essential help provided by Missy Roser. 


\begin{abstract}
"The only statement I want to make is that I am an innocent man convicted of a crime I did not commit. I have been persecuted for twelve years for something I did not do. From God's dust I came and to dust I will return, so the Earth shall become my throne."
\end{abstract}

Cameron Todd Willingham, minutes before his execution February 17, 2004

\title{
I. INTRODUCTION
}

Miscarriages of justice and wrongful convictions are a pervasive reality in America's criminal justice system. ${ }^{1}$ They undermine a fundamental premise of life in a free society, namely that "every individual going about his ordinary affairs have confidence that his government cannot adjudge him guilty of a criminal offense without convincing a proper fact finder of his guilt with utmost certainty." ${ }^{2}$ Not only are they unjust, wrongful convictions dilute the deterrent effect of criminal punishment. ${ }^{3}$

In this paper we examine news coverage of miscarriages of justice in the death penalty system and the release of death row inmates to try to understand the public life of exonerations. In so doing we contribute to a line of research on the problem of wrongful conviction that extends back to the early twentieth century when Yale Law School professor Edwin Borchard published one of the first books on wrongful conviction, Convicting the Innocent. ${ }^{4}$ While Borchard documented sixty-five cases in which innocent people were convicted, ${ }^{5}$ it is difficult to know with any precision the totality of the issue. ${ }^{6}$ However, we do know that many factors contribute to miscarriages of justice, including eyewitness misidentification, police and prosecutorial overzealousness or bad faith, community pressure for conviction, errors in criminal record keeping and false confessions. ${ }^{7}$ In all of this, race plays a significant role with racial/ethnic minorities being overrepresented among the wrongfully convicted. ${ }^{8}$

Richard A. Leo, Rethinking the Study of Miscarriages of Justice: Developing a Criminology of Wrongful Conviction, 21 J. CONTEMP. CRIM. JUST. 201 (2005).

2 In re Winship, 397 U.S. 358, 364 (1970).

3 Henrik Lando, Does Wrongful Conviction Lower Deterrence?, 35 J. Legal Stud. 327 (2006); Nuno Garoupa \& Matteo Rizzolli, Wrongful Convictions Do Lower Deterrence, 168 J. Institutional \& TheORETical Econ. 224 (2012).

4 Edwin M. Borchard \& E. Russell Lutz, Convicting the InNocent: Errors of Criminal Justice (1932).

5 D. Michael Risinger, Innocents Convicted: An Empirically Justified Factual Wrongful Conviction Rate, 97 J. CRim. L. \& Criminology 761 (2007).

6 Kimberley A. Clow et al., Public Perception of Wrongful Conviction: Support for Compensation and Apologies, 75 ALB. L. Rev. 1415 (2012).

7 C. Ronald Huff et al., Convicted but Innocent: Wrongful Conviction and Public Policy (1996); Arye Rattner, Wrongful Conviction and the Criminal Justice System, 12 Law \& Hum. Behav. 283 (1988).

8 Samuel R. Gross et al., Exonerations in the United States 1989 Through 2003, 95 J. CRIM. L. \& Criminology 523 (2005); Karen F. Parker et al., Racial Bias and the Conviction of the Innocent, in Wrongly Convicted: When Justice Fails 114 (Saundra Davis Westervelt \& John A. Humphrey eds., 2001); Angela Yvonne Davis, Women, Race \& Class (1983); 
What is true for the entire criminal justice system in general is also true in death cases. ${ }^{9}$ The problem of erroneous convictions in such cases has become central to the contemporary abolition movement, ${ }^{10}$ and error reduction has been an important, though not uncontested, part of the jurisprudence of capital punishment for almost 50 years. ${ }^{11}$ In 1972, the United States Supreme Court held that the arbitrariness and capriciousness of death sentencing rendered it unconstitutional. ${ }^{12}$ Four years later, in Gregg v. Georgia, the Court decided that the death penalty was not per se cruel and unusual punishment according to the Eighth Amendment. ${ }^{13}$ The Court believed that the reduction in the number of death-eligible crimes would reduce the errors endemic to the capital punishment system. ${ }^{14}$ Because the Court found that "death is different," 15 it mandated what some have called "super due process" to ensure the reliability of death penalty determinations. ${ }^{16}$ As Justice Sandra Day O'Connor once noted, "This Court has gone to extraordinary measures to ensure that the prisoner sentenced to be executed is afforded a process that will guarantee, as much as is humanly possible, that the sentence was not imposed out of whim, passion, prejudice, or mistake."17

Scholars estimate that of the 2,600 people currently on death row, approximately 1 in 25 , or 104 people, are actually innocent. ${ }^{18}$ Incompetent defense

Campbell Robertson, A Lynching Memorial Is Opening. The Country Has Never Seen Anything Like It., N.Y. TIMES (Apr. 25, 2018), https://www.nytimes.com/2018/04/25/us/ lynching-memorial-alabama.html; The National Memorial for Peace and Justice, EQUAL Justice InITIATIVE, https://museumandmemorial.eji.org/memorial (last visited Jan. 7, 2020).

9 See When Law Fails: Making Sense of Miscarriages of Justice (Charles J. Ogletree, Jr. \& Austin Sarat eds., 2009).

10 Carol S. Steiker \& Jordan M. Steiker, The Seduction of Innocence: The Attraction and Limitations of the Focus on Innocence in Capital Punishment Law and Advocacy, $95 \mathrm{~J}$. CRim. L. \& CRIMINology 587, 594 (2005).

11 See Jordan M. Steiker, The American Death Penalty: Constitutional Regulation as the Distinctive Feature of American Exceptionalism, 67 U. Miami L. Rev. 329 (2013); Carol S. Steiker \& Jordan M. Steiker, Sober Second Thoughts: Reflections on Two Decades of Constitutional Regulation of Capital Punishment, 109 HaRv. L. REv. 355 (1995); Jordan S. Rubin, Justices Weigh Finality, Windfalls in Complex Capital Case (1), BLOOMBerG LAW (Dec. 11, 2019, 5:43 PM), https://news.bloomberglaw.com/us-law-week/justicesweigh-whether-new-law-applies-to-old-capital-cases; Daniel Medwed, Grand Finality, in Final Judgments: The Death Penalty in American LaW and Culture 90 (Austin Sarat ed., 2017); Anna Arceneaux, In America, People on Death Row Can Be Executed While the Supreme Court Reviews Their Cases, American Civil Liberties Union (Mar. 8, 2019, 12:45 PM), https://www.aclu.org/blog/capital-punishment/america-peopledeath-row-can-be-executed-while-supreme-court-reviews-their.

12 Furman v. Georgia, 408 U.S. 238 (1972).

13 Gregg v. Georgia, 428 U.S. 153, 188 (1976).

14 Medwed, supra note 11.

15 "The penalty of death is different in kind from any other punishment imposed under our system of criminal justice.”, Gregg v. Georgia, 428 U.S. 153, 188 (1976) (Stewart, J.).

16 Ronald J. Tabak, The Egregiously Unfair Implementation of Capital Punishment in the United States: 'Super Due Process' or Super Lack of Due Process?, 147 Proc. Aм. Pнil. Soc'y 13 (2003).

17 Eddings v. Oklahoma, 455 U.S. 104, 118 (1982) (O’Connor, J., concurring).

18 See Gross et al., supra note 8; Andrew Cohen, Yes, America, We Have Executed an Innocent Man, The AtLantic (May 14, 2012), https://www.theatlantic.com/national/ archive/2012/05/yes-america-we-have-executed-an-innocent-man/257106/. 
attorneys, police and prosecutorial misconduct, faulty jury instructions, and faulty forensic science all contribute to the problem of miscarriages of justice in death cases. Craig Haney additionally suggests that the media, which sometimes spreads false information about a particular death case, is also a significant contributor to miscarriages of justice. ${ }^{19}$

Since 1973, 167 people from 28 different states have been exonerated from death row. ${ }^{20}$ In other words, for every nine people executed in the United States, one has been freed following discovery of error. Some were freed by DNA testing and others were not. ${ }^{21}$ Some received compensation for the time they lost, but most did not. These cases and experiences are both unique and shockingly similar.

Even the discovery of the many factors that can lead to wrongful conviction is often insufficient to provide the legal basis for releasing someone from death row. ${ }^{22}$ Jon B. Gould notes that "wrongful convictions are only overturned when there [is] 'hard,' irrefutable evidence that the defendant did not commit a crime."23 Exoneration requires a reversal of something that was previously thought to be true. Often the same officials who were involved in the original erroneous conviction must come to recognize and accept their error and the convict's innocence. ${ }^{24}$

Increased use of DNA testing has played a key role in uncovering error in murder and other kinds of cases. Such testing was first admitted as evidence in the New York case, People v. Wesley. ${ }^{25}$ When errors are uncovered and convictions are overturned, with or without the use of DNA, those freed from death row seldom receive any compensation for the injustice done or their time served on death row. ${ }^{26}$ Of the 167 death row exoneration cases, only 50 received compensation. ${ }^{27}$ This is

19 Craig Haney, Exoneration and Wrongful Condemnations: Expanding the Zone of Perceived Injustice in Death Penalty Cases, 37 Golden Gate U. L. Rev. 131 (2006).

20 Innocence Database, DeAth Penalty Information Center, https://deathpenaltyinfo. org/policy-issues/innocence-database (last visited Jan. 20, 2020).

21 Just over $50 \%$ of death row exonerations result from the use of DNA or from some other means of establishing that the exonerees were "factually innocent." In other cases, the evidence obtained after trial showed that the state had not met its burden of proving legal guilt. Description of Innocence Cases, Death Penalty Information Center, https:// deathpenaltyinfo.org/policy-issues/innocence/description-of-innocence-cases (last visited Mar. 30, 2020).

22 Herrera v. Collins, 506 U.S. 390 (1993).

23 Jon B. Gould \& Richard A. Leo, The Path to Exoneration, 79 Alb. L. Rev. 325 (2016).

24 Carpitcher v. Commonwealth, 641 S.E.2d 486, 492 (Va. 2007).

25 George Bundy Smith \& Janet A. Gordon, The Admission of DNA Evidence in State and Federal Courts, 65 Fordham L. Rev. 2456 (1997).

26 In the past 10 years, only 6 of 27 exonerees have received compensation. This number comes from our review of available information. See also Jean Coleman Blackerby, Life After Death Row: Preventing Wrongful Capital Convictions and Restoring Innocence After Exoneration, 56 VAND. L. REv. 1179 (2003).

27 Exonerees can attempt to receive compensation for their wrongful convictions by one of three methods. The first is via the Civil Rights Act of 1987 . However, these claims are complicated because they require demonstrating prosecutorial, defense, lab, or police misconduct. See Tiffany Charity Merritt, Legal and Extra-Legal Factors That Influence Redress Received by Death Row Exonerees (May 1, 2017) (unpublished M.A. thesis, University of North Carolina at Greensboro (on file with the Walter Clinton Jackson Library, University of North Carolina at Greensboro). The second method exonerees may 
in part due to the complexity of the processes for petitioning for compensation and the disparities among state compensation statutes. ${ }^{28}$ Of the 50 death row exonerees who have received compensation, the amount they received varied from \$29 million after 33 years of wrongful imprisonment ${ }^{29}$ to $\$ 100$, a pair of pants, and a shirt after 18 years of wrongful imprisonment. ${ }^{30}$ Those fortunate enough to be exonerated and compensated after a wrongful conviction still must deal with the lasting consequences of that experience. ${ }^{31}$

Exoneration, by definition, is a kind of absolution. The word has Latin origins. “The 'ex' means 'away' or 'from.' And the 'onerate' comes from the Latin word, 'onus'.... In Latin, [onus] literally meant weight ... So exonerate means to lift the weight from or to remove the weight of." ${ }^{32}$ Exoneration is vindication. It is clear, specific, and undeniably good. Exoneration is a statement about truth, about an objective fact.

Nonetheless, according to Marc Bookman, the United States Supreme Court has

repeatedly declined to hold that the federal Constitution allows for so-called freestanding claims of innocence, that is, the right to be let out of prison simply because you didn't do it, without any other procedural or 'technical' violation of the law. In the United States, the inmate who raises a compelling case of innocence after a constitutionally proper trial may well be doomed. ${ }^{33}$

use is lobbying their state legislatures for private compensation bills. Here compensation comes directly from the state treasury to the exoneree and the legal obstacles are not as high. The third method of obtaining compensation is through a preexisting state statute that determines what exonerees are awarded after they have been released. For example, Virginia law provides that after a conviction is vacated the maximum compensation award be " $90 \%$ of the VA per capita personal income - for each year of incarceration." See VA. Code AnN. §§ 8.01-195.10-195.13 (West).

28 Only 33 states have such statutes. The remaining 17 do not have established plans for handling providing compensation for people wrongfully convicted of committing a crime.

29 Peter Limone, National Registry of Exonerations, https://www.law.umich.edu/ special/exoneration/Pages/casedetail.aspx?caseid=3383 (last visited Mar. 30, 2020).

30 Juan Roberto Melendez, National Registry of Exonerations, https://www.law.umich. edu/special/exoneration/Pages/casedetail.aspx?caseid=3465 (last visited Mar. 30, 2020).

31 Ronald Keine, When Justice Fails: Collateral Damage, 75 ALb. L. Rev. 1501 (2012); Leo, supra note 1.

32 Edgar B. Herwick III, Does 'Exonerate' Mean What We Think It Means?, WGBH News (Apr. 3, 2019), https://www.wgbh.org/news/national-news/2019/04/03/doesexonerate-mean-what-we-think-it-means. See also Glossary, The National Registry of Exonerations, https://www.law.umich.edu/special/exoneration/Pages/glossary.aspx (last visited Mar. 30, 2020).

33 Marc Bookman, Does an Innocent Man Have the Right to Be Exonerated?, THE ATLANTIC (Dec. 6, 2014), https://www.theatlantic.com/national/archive/2014/12/ does-an-innocent-man-have-the-right-to-be-exonerated/383343/. See also Lara Bazelon, Scalia's Embarrassing Question, SLate (Mar. 11, 2015, 9:37 AM), https:// slate.com/news-and-politics/2015/03/innocence-is-not-cause-for-exoneration-scaliasembarrassing-question-is-a-scandal-of-injustice.html. 
As Justice Scalia once reminded his colleagues, the Court has

never held that the Constitution forbids the execution of a convicted defendant who has had a full and fair trial but is later able to convince a habeas court that he is 'actually innocent.' Quite to the contrary, we have repeatedly left that question unresolved, while expressing considerable doubt that any claim based on alleged 'actual innocence is constitutionally cognizable. ${ }^{34}$

Exoneration touches on a central fear regarding the death penalty, namely that the United States has, at some point in history, executed an innocent person. Statistically, the execution of an innocent person seems very likely, ${ }^{35}$ but no state has ever admitted to putting an innocent person to death. It is seemingly impossible to actually prove innocence after an execution so instead we are left with those whose narrow escapes we can document. ${ }^{36}$

Exoneration is a story about a past wrong made right, about a death sentence no longer on the table and freedom granted. Because death has been successfully and rightfully avoided, there is a note of safety in the story of an exoneration and the promise of something close to a happy ending. The documentary film Time Simply Passes, which focuses on James Richardson, who was convicted of murdering his own children in Florida, offers one example of this pattern. ${ }^{37}$

The opening scenes include sun-soaked, shaky footage, seemingly taken by a family member so overcome with joy that he cannot hold the camera steady. Richardson looks towards the sky, squinting into the light and proclaims "Thank God, I'm free. I don't have to worry about that trouble no more. It's all over," and is then embraced by an unknown man. ${ }^{38} \mathrm{~A}$ news program reports that Richardson, after one day of freedom, has "never looked better" while he strolls barefoot on the beach with the lawyer who freed him. ${ }^{39}$

This is the reassuring picture of the exonerated, a person who has known great suffering but whose innocence now is his greatest possession. The joy of exoneration is so sharply separated from the actual process of his conviction, confinement, and appeals that it feels like a resurrection and the start of a completely different life, a different story, making the earlier suffering feel far away, boxed in, and, most

34 Corey Adwar, Justice Scalia Says Executing the Innocent Doesn't Violate the Constitution, Business INSIDER (Sept. 4, 2014, 10:00 PM), https://www.businessinsider. com/antonin-scalia-says-executing-the-innocent-is-constitutional-2014-9? $\mathrm{r}=\mathrm{US} \& \mathrm{IR}=\mathrm{T}$.

35 National Academy of Sciences Reports Four Percent of Death Row Inmates Are Innocent, InNOCENCE PROJECT (Apr. 28, 2014), https://www.innocenceproject.org/nationalacademy-of-sciences-reports-four-percent-of-death-row-inmates-are-innocent/. See also Cohen, supra note 18; Tom Jackman, Essay: The Problem of Innocence in Death Penalty Cases, WAsh. Post (Aug. 28, 2017, 5:16 PM), https:/www.washingtonpost.com/news/ true-crime/wp/2017/08/28/essay-the-problem-of-innocence-in-death-penalty-cases/.

36 Associated Press, Judge Denies DNA Testing That Could Exonerate Tennessee Man Executed 13 Years Ago, WBIR (Nov. 18, 2019, 8:55 AM), http://www.wbir.com/ article/news/crime/lawyers-dna-tests-could-exonerate-man-executed-13-years-ago/51326b056b-2297-461c-a19b-a18bafa5ada0.

37 Time Simply Passes (Tanman Films 2015).

$38 \quad$ Id.

$39 \quad$ Id. 
importantly, over. That is how exoneration is meant to feel for the exonerated and be communicated to the public. Richardson is part of the exoneration canon, the value of his life and the potential for its loss now realized in full.

Yet life after exoneration is seldom easy. ${ }^{40}$ Time Simply Passes complicates the picture of post-exoneration life, showing people discussing Richardson's financial struggles after his release from death row and his fight for compensation from the state which put him on death row. Richardson is taken care of by a white family while he seeks redress from Florida through the Victims of Wrongful Incarceration Act of $2008 .^{41}$ Initially, he was denied compensation because he was unable to satisfy the Act's requirement that he provide DNA evidence or some other affirmative proof of innocence.

In 2014, the Florida legislature authorized compensation for Richardson. After final passage of that legislation, as he watched from the gallery, legislators gave him a standing ovation. The documentary offers its viewers reassurance that rebirth is possible after exoneration. But, as Cathy Caruth's writings on traumatic experience and its denial of narrative finality would predict, something still doesn't feel quite right. ${ }^{42}$

Exoneration stories generally cover neither suffering, nor acknowledge the lasting harm done. Instead, they highlight the value of the lives at stake and the grace they earned. This is the story people expect from an exoneration: conviction is horrible and shocking; death row is deeply traumatic; life on the outside is complicated and still painful but unquestionably better. Exonerees are grateful to be alive, and they are alive because the truth that once was obscured is now known.

Nonetheless, there is a lively debate about the significance of false convictions and subsequent exonerations for the legal system. Some seize on the fact that "mistakes were caught before these prisoners were put to death" as "proof that the system works." No matter that many of the exonerated were freed solely because of the hard work of defense attorneys and non-profit groups dedicated to identifying instances of wrongful conviction or the chance discovery of some new evidence. No matter that some of the convictions resulted from police misconduct or false witness testimony. The system is working because, in the end, the state did not kill an innocent person.

Others argue that false convictions and exonerations show that "Our death penalty system has been - by any measure - a failure." ${ }^{44}$ As an editorial in the New York Times put it, "[E]xonerations are not a sign that the system works." 45

40 Saundra D. Westervelt \& Kimberly J. Cook, Life After Death Row: Exonerees' Search for Community and Identity (2012). See also, Scott Pelley, Life After Death Row, CBS News (July 31, 2016), https://www.cbsnews.com/news/60-minutes-life-afterdeath-row-exoneration-2/.

41 See Victims of Wrongful Incarceration Compensation Act, Fla. STAT. §§ 961.01-961.07.

42 Cathy Caruth, Unclaimed Experience: Trauma, Narrative, and History (20th ed. 2016).

43 Bush Blind to Execution's Dangers, St. Petersburg Times, Feb. 18, 2000, at A14.

44 Liliana Segura \& Jordan Smith, "There Are Innocent People on Death Row" - Citing Wrongful Convictions, California Governor Halts Executions, The InTERCEPT (Mar. 13, 2019), https://theintercept.com/2019/03/13/california-death-penalty-moratorium/.

45 Innocents on Death Row, N.Y. TIMES (May 23, 1999), https://www.nytimes. com/1999/05/23/opinion/innocents-on-death-row.html. 
For those who have been wrongfully convicted and sentenced to death, the system is broken. It is not a matter of the 'rotten apples' in the system who have fallen short of their ethical obligations. Rather their cases point to the 'contaminated orchard' where the entire system - from prosecution to incarceration and ultimately to post-exoneration - inflicts trauma, and irreversible damage to them, where the final insult is an inability by anyone to 'own' the state's role in the tragedy. ${ }^{46}$

In what follows we show how the release of innocent people from death row plays out in what we call the public life of exoneration. We examine the way newspapers tell their stories and the various tilts and tendencies that characterize their presentations. While publicized instances of wrongful conviction and exonerations in America date back to $1819,{ }^{47}$ scholarly attention to the way they have been publicized is relatively recent. Available research differs in the approaches used and in the conclusions reached about the impact of news coverage on the public's support for, or belief in the legitimacy of, the death penalty. ${ }^{48}$

In one of the first and most important examples of such attention, Frank Baumgartner and his collaborators conducted a content analysis of coverage of the death penalty in the New York Times from 1960 to $2005 .{ }^{49}$ That analysis demonstrates substantial changes in the "framing" of the debate about capital punishment. Baumgartner et. al. found that over a period of more than 40 years, the emphasis of the death penalty coverage has shifted from moral and/or constitutional issues to the administration of capital punishment, and since 1993, "attention has increasingly focused on questions relating to the defendants in criminal trials rather than to victims. ${ }^{150}$ News coverage has recently been dominated by stories about the fairness of the death penalty, and as the authors document, there has been an increase in "anti-death penalty tone over the last decade." ${ }^{11}$ They note that, "the average number of stories an individual exonerated from death row today is likely to get is more than 13 times the number that someone exonerated [before the

46 @ Saundra D. Westervelt \& Kimberly J. Cook, Framing Innocents: The Wrongly Convicted as Victims of State Harm, 53 Crime, L. \& Soc. Change 259, 274 (2010). See also Don Terry, Survivors Make the Case Against Death Row, N.Y. Times (Nov. 16, 1998), https://www.nytimes.com/1998/11/16/us/survivors-make-the-case-againstdeath-row.html; Herbert H. Haines, Flawed Executions, the Anti-Death Penalty Movement, and the Politics of Capital Punishment, 39 Soc. Probs. 125 (1992).

47 See Stuart Banner, The Death Penalty: An American History 212 (2002).

48 Other scholars have studied the impact of public awareness of miscarriages of justice on public support for capital punishment without examining the news coverage that produced such awareness. See, e.g., James D. Unnever \& Francis T. Cullen, Executing the innocent and support for capital punishment: Implications for public policy, 4 Criminology \& Pub. Pol'y. 3 (2005); Amy L. Anderson et al., Age, Period, and Cohort Effects on Death Penalty Attitudes in the United States, 1974-2014, 55 Criminology 833 (2017).

49 Frank R. Baumgartner et al., The Decline of the Death Penalty and the DisCOVERY OF INNOCENCE (2008).

$50 \quad I d$. at 127.

${ }^{51} \quad I d$. at 121. 
1990s] could expect" 52 They conclude that this fact helps explain changes in public attitudes toward capital punishment as well as in the number of death sentences.

Another more limited study, by Laura Rozier, focused on 30 news clips from the Vanderbilt Television News Archives between 1981 and 2014. ${ }^{53}$ Like Baumgartner, Rozier found substantial changes in news coverage of capital punishment. DNA was not discussed at all in the 1980s but by the year 2000 it was mentioned in $29 \%$ of clips about the death penalty. ${ }^{54}$ However, unlike Baumgartner, Rozier observes that the impact of such new coverage depended on the substance not just the fact of coverage. As she argues, "Individuals are more likely to believe that a person who is exonerated using DNA evidence is innocent than one who is not, even if the criminal justice system was confident enough in both to set them free." ${ }^{55}$

A third study, by University of Cincinnati professor David Niven, examined the way newspapers in the American South covered death row exonerations. ${ }^{56} \mathrm{He}$ too focused on the substance, not just the fact of coverage. Niven argues that "if the media gloss over the facts of the exoneration story and the larger trend, then the effects of exonerations may be blunted, with the media, in effect, acting to protect the death penalty from popular scrutiny." 57 Niven found that "by a wide margin [media] coverage gives voice to supportive words which portray the exoneration as an isolated mistake, or, perversely, as evidence the system is working." ${ }^{58}$ In contrast to Baumgartner, he concludes that newspaper coverage "helped to bolster support for death sentences in the South. ${ }^{59}$

Following Rozier and Niven, we studied the substance of newspapers' coverage of exonerations. Like them we analyzed what news stories said about the exonerations they described. We focused on the five states which, from 1972-2019, had ten or more exonerations. During that period, they were Florida, Illinois, Texas, Louisiana, and Oklahoma. ${ }^{60}$ We examined the two largest circulation newspapers in each state. ${ }^{61}$ We relied on the Death Penalty Information Center's list of exonerations. ${ }^{62}$

$52 \quad I d$. at 26.

53 Laura Rozier, The Media, the Innocent, and the Public: A Nuanced Look at Exonerations and Public Opinion of Capital Punishment (Apr. 27, 2015) (unpublished B.A. thesis, Weinberg College of Arts and Sciences, Northwestern University) (on file with the Department of Political Science, Weinberg College of Arts and Sciences, Northwestern University).

$54 \quad I d$. at 39.

55 Id. at 44.

56 David Niven, Southern Newspaper Coverage of Exonerations from Death Row, $11 \mathrm{~J}$. Crim. Just. \& Popular Culture 20 (2004).

57 Id. at 27.

$58 \quad$ Id.

$59 \quad I d$.

60 Since we completed the research for this article, a tenth man has been exonerated in North Carolina.

${ }^{61}$ There is no definitive information regarding a ranking of newspaper distribution because such information is made public only for the purposes of advertising, and newspapers must pay to be included. However, we used the SRDS Media Advertising Source and the Gale Directory Of Publications to choose the newspapers with the largest listed distribution numbers in those texts. We did not take into account Sunday distribution numbers or online circulation.

62 Innocence Database, Death Penalty Information Center (Mar. 30, 2020), https:// deathpenaltyinfo.org/policy-issues/innocence-database. 
News coverage of exonerations is, of course, governed by the journalistic conventions of the newspapers which cover them. Those conventions emphasize both the need for independence and balance. ${ }^{63}$ Contemporary journalism foregrounds principles of fairness and balance in the service of "objectivity." 64

Michigan State University professor Frederick Fico observes that "all the codes of ethics of major news organizations and professional associations command fairness," and that "courts in at least 10 states have adopted a 'neutral reportage' privilege in libel actions which protects journalists when they have presented balanced assertions from competing sources in stories about controversy." 65 According to journalistic convention, balance means presenting all sides of an issue, and giving them equal weight. ${ }^{66}$ In this effort, journalists mimic the third person voice by effectively becoming a distant observer to the matter being reported. ${ }^{67}$

Our inquiry focuses on the aftermath of capital cases - once they have already been classified as wrongful convictions and the ex-defendant has been exonerated. As we will see, journalistic conventions are very consequential in reporting on such cases. ${ }^{68}$ Our database contains 1717 articles which mention a death row exoneration. One thousand and thirty-six of those articles contain some explanation of, or argument about, why someone was released from death row. In the latter group, we analyzed whether the explanations offered referred to DNA or police misconduct, whether they included a substantial case history, whether they mentioned the granting of, or ongoing fight for, compensation, whether they included any sort of follow-up with the exoneree, whether they contained any mention of a state apology, whether a pardon was mentioned, and mentions of blame or fault, systemic failure, reasons for compensation or lack thereof, the necessity for apology, questioning of innocence, and of the word justice/injustice or luck and misfortune, as well as their use (or lack thereof) of the word exoneration.

In what follows, we ask whether coverage of exoneration explains how a miscarriage of justice occurred. Why? Has it happened to other people, past or present? Is the death of an innocent person an acceptable risk? We conclude that the public discourse surrounding exoneration, while providing evidence of the death

63 Christopher B. Daly, Covering America: A Narrative History of a Nation's Journalism 154 (2012). See also David T. Z. Mindich, Just the Facts: How "Objectivity" Came to Define American Journalism (1998).

64 Joel Kaplan, Objectivity and Balance: Today's Best Practices in American Journalism, https://publicmediaintegrity.org/wp-content/uploads/cpb_BestPractices_Kaplan.pdf (last visited Mar. 30, 2020).

65 Frederick Fico et al., Fairness and Defamation in the Reporting of Local Issues (AEJMC 1997 Conference Papers) (on file with Michigan State University).

${ }_{66}$ Michael Schudson, The Objectivity Norm in American Journalism, 2 Journalism 149 (2001).

67 Robert M. Entman, Democracy Without Citizens: Media and the Decay of American Politics (1989); Declan Fahy, Objectivity, False Balance, and Advocacy in News Coverage of Climate Change, OxFord Research ENCYClopedia OF Climate Science (Mar. 29, 2017), https://oxfordre.com/climatescience/view/10.1093/ acrefore/9780190228620.001.0001/acrefore-9780190228620-e-345; D. J. Koehler, Can Journalistic 'False Balance' Distort Public Perception of Consensus in Expert Opinion?, 22 J. EXPerimental Psychol.: APPLied 24 (2016).

68 Rob Warden, The Revolutionary Role of Journalism in Identifying and Rectifying Wrongful Convictions, 70 UMKC L. Rev. 803 (2002). 
penalty system's most consequential flaws, serves as much to preserve that system as to challenge it. ${ }^{69}$

\section{The LANGUAGE OF EXONERATION}

Table 1. Use of the word "Exoneration".

\begin{tabular}{|c|c|}
\hline & Use of word "Exoneration" \\
\hline Yes & $426(24.8 \%)$ \\
\hline No & $1,291(75.2 \%)$ \\
\hline Total & 1,717 \\
\hline
\end{tabular}

Exoneration is the word used by every organization working on the problem of wrongful convictions and by the DPIC in its list of people released from death row. This word, as we noted above, suggests that those people no longer carry the burden of guilt, whether factual or legal. Yet one of the most striking facts of newspaper coverage of cases in which death row inmates are freed after the discovery of a miscarriage of justice is the infrequency with which it uses the word exoneration. Only $24.8 \%$ of newspaper articles that we examined mention that word or a derivative thereof. ${ }^{70}$

One example of the avoidance of the language of exoneration occurs in news coverage of the Florida case of Joseph Green Brown. He was convicted of the 1973 rape and murder of Earlene Treva Barksdale, the wife of a prominent Tampa attorney. Green, also known by his Swahili name "Shabaka," was born in Charleston, South Carolina, but moved to Florida in search of work in the early 1970s. There he met Robert Floyd, and the two ultimately carried out a string of crimes, including robbing a Holiday Inn. The same day as that robbery, Barksdale was murdered in the back of her clothing store, from which $\$ 100$ was also found to be missing. The similarities between the two crimes, committed within hours of each other, and statements made by Floyd implicating Brown after his arrest for the Holiday Inn robbery led police to arrest the twenty-four-year-old.

Brown's 1974 trial, in front of an all-white jury, took just five days. He was convicted of first-degree murder, rape, and robbery and sentenced to death. The prosecution's star witness was Floyd, who had accepted a plea deal in exchange for his testimony. Yet the prosecution denied that such a deal had been made in closing statements during the trial. Moreover, the prosecution also falsified ballistics evidence, claiming that Brown's .38 caliber handgun was the murder weapon, despite an FBI analysis that had eliminated that possibility.

69 Richard Nobles \& David Schiff, Understanding Miscarriages of Justice: LaW, the MEDIA, AND THE INEVITABILITY OF CRISIS (2000).

70 Newspapers sometimes use the word, without applying it to a specific case, when they name an organization (National Registry of Exonerations etc.) or refer to a list of the states' "exonerees." In addition, there are other words and phrases which can have the same effect as exoneration, "innocence" or variants thereof being the obvious example. Exoneration is not a principally legal term (some states have introduced exoneration into the legal lexicon of compensation, but it remains largely outside of that world). 
At one point during his long imprisonment, Brown came within 24 hours of execution. ${ }^{71}$ His conviction ultimately was overturned on appeal after the court found that the prosecution knowingly allowed (and encouraged) Floyd to provide false testimony regarding his plea deal. After Brown's conviction was overturned, the prosecution decided they did not have enough evidence to retry Brown and he was released from prison. Brown maintained his innocence the entire time.

Yet the Tampa Bay Times coverage of Brown's release describes him as "a convicted murderer imprisoned on death row since 1974." The paper said that Brown was "freed because Hillsborough County prosecutors, ordered to retry the case, decided they lacked the evidence to prove the original murder charge." 72 In fact, Brown at this point in his life was not a convict at all. He was an innocent man in the eyes of the law, but the coverage seems to tell the story of guilt, "a convicted murderer" just walking away from punishment, free and easy. The newspaper avoids the use of the term exonerated to refer to Brown while suggesting instead that he escaped punishment on a legal technicality. ${ }^{73}$

The Florida Sun-Sentinel's coverage of Brown's release from death row also avoids referring to him as exonerated. Its headline-"Man Free After Death Row Stay"-with its reference to a "stay" makes death row seem like a bed and breakfast where many choose to spend some years. ${ }^{74}$ The article that follows the headline is remarkably cavalier regarding Brown's near-death: "A death-row inmate who came within a day of being electrocuted is a free man today. Joseph Green Brown had spent 13 years under the death sentence for the 1973 robbery, rape and murder of Earlene Evans Barksdale." ${ }^{.75}$ Here again, the newspaper makes no mention of actual innocence, or exoneration. Brown remains an ex-inmate, permanently marked by his overturned conviction.

Michael Toney was convicted for the 1985 bombing-murder of three people at a trailer park in Lake Worth, Texas. ${ }^{76}$ At first, the police could not identify a motive for the murder, and they eventually became convinced that the bomb was intended for a neighbor who was selling weapons illegally. The case went cold for ten years until the federal government's Bureau of Alcohol, Tobacco, and Firearms reopened investigations into all unsolved domestic bombings. During that investigation an inmate then informed police that he had heard Michael Toney confess to the bombing. He recanted this statement before Toney's trial.

However, police convinced Toney's ex-wife to say that she remembered being near the site of the bombing on the night of the murders, along with Toney's then-bestfriend, Christopher Meeks. She also claimed that Toney had carried a briefcase similar to the one used in the bombing. Meeks corroborated her testimony, and Toney was convicted and sentenced to death, despite the complete lack of a motive or any physical

71 The reported number of hours varies. In some cases it is as low as fifteen.

72 Bob C. Port, Charges Dropped for Death Row Prisoner, St. Petersburg Times, Mar. 7 , 1987, at 7B.

73 John Davison Lawson, Technicalities in Procedure Civil and Criminal, 1 J. CRIM. L. \& Criminology 63 (1910).

74 The Associated Press, Man Free after Death Row Stay, Fla. Sun-Sentinel, Mar. 7, 1987 , at 23A.

$75 \quad I d$.

76 Alexandra Gross, Michael Toney, National Registry of Exonerations, https://www. law.umich.edu/special/exoneration/Pages/casedetail.aspx?caseid=3692 (last visited Feb. 13, 2020). 
evidence. His initial appeals were denied, but ultimately his lawyers discovered that police had fed information to Meeks and the former Mrs. Toney and withheld documents contradicting their testimony. They were able to persuade a judge to throw out his conviction, after which the prosecutor's office decided not to retry the case.

In Toney's case, no one discovered new evidence of innocence. There was simply never any real evidence of guilt. Testimony materialized and disappeared quickly, but, in the meantime, a man was sentenced to death. This is not the kind of case which typically generates much news coverage. There was no DNA evidence, no tortured false confession, and the man in question had already served time for other crimes. In this case many people, specifically the police, behaved badly, and news coverage of Toney's case struggled to come to terms with this reality.

Throughout his time on death row, the Houston Chronicle portrayed Toney as desperate to draw attention to his case and as eventually getting his way. One article's opening passage is followed by the revelation of the release of "14 documents...that cast doubt on the testimony of two key witnesses against him." 77 In addition, the article never mentions either exoneration or innocence (beyond noting Toney's own claim). It concludes by saying that the prosecutor's office intends to retry the case "but has not made a final decision." never retried, because there was no evidence of Toney's guilt.

The Dallas Morning News' sole article on Toney also does not mention actual innocence. ${ }^{79}$ Following the conventions of balanced reporting, the article quotes the defense and then the prosecution. The prosecutor admits that he should have turned over the exonerating evidence, but still believes that Toney is guilty. ${ }^{80}$ The newspaper reported that Toney's ex-wife stood by her testimony but also now admits to also memory-loss caused by toxic exposure during her military service in the Persian Gulf War. ${ }^{81}$

Newspaper coverage of other cases uses the language of exoneration, but in a way that casts doubt on it. It does so by using qualifiers, like "could have," "might have" 83 or "potentially" 84 to describe exonerations. And some articles were more direct in calling attention to expressions of doubt about innocence. Thus coverage of Curtis McCarty's release from Oklahoma's death row refers to him only as a "man formerly on death row." It mentions that in McCarty's case "authorities don't consider him to be exonerated, despite District Judge Twyla Mason Gray's decision to dismiss the murder charge against him." ${ }^{85}$

\footnotetext{
$I d$.

Id.

$I d$.

$I d$.
}

81 Doug J. Swanson, 1985 Murder Case Tarrant Withheld Evidence, DA Says Documents Favorable to Death Row Inmate; Retrial Expected in Bomb Slayings, Dall. MoRning News, Oct. 3, 2008, at 1B.

82 Ted Gregory, Dupage 7 Hearing Fuels War of Lawyers, Chi. Trib. (Nov. 10, 1997), https://www.chicagotribune.com/news/ct-xpm-1997-11-10-9711100213-story.html.

83 Ray Robinson, Judges Differ on Evidence in Bowen Case, OкLahoman (Jan. 28, 1986), https://oklahoman.com/article/2135814/judges-differ-on-evidence-in-bowen-case.

84 Griff Palmer, Stay Denied, But Bowen Still in Prison, Oklahoman (Jan. 24, 1986), https://oklahoman.com/article/2135320/stay-denied-but-bowen-still-in-prison?.

85 Jay F. Marks, Ex-Inmate Suing City, Chemist, OкLaномаn (Dec. 27, 2007), https:// oklahoman.com/article/3185641/ex-inmate-suing-city-chemist. 


\section{INNOCENCE: AN UNSETTLED QUESTION}

Table 2. Questioning the Exoneree's Innocence ${ }^{86}$

\begin{tabular}{|c|c|}
\hline & Innocence Questioned \\
\hline Yes & $235(22.7 \%)$ \\
\hline No & $801(77.3 \%)$ \\
\hline Total & 1,036 \\
\hline
\end{tabular}

If refusing to actually use the word exoneration, or softening its effect with various qualifiers, expresses ambivalence about the innocence of those released from death row, then the outright questioning of innocence is the next step towards undermining the impact of such exonerations. ${ }^{87}$ While legally those released from death row are innocent of the crime for which they had been convicted, ${ }^{88}$ as Table 2 shows, $22.7 \%$ of the articles we examined contain some statement or statements questioning the exoneree's innocence. While clearly a minority of the news stories, that nearly a quarter do so represents a significant fact of the public life of exoneration.

In the instances when news stories question a death row exoneree's innocence, most of the time (68.3\%) they do so by quoting a state official, namely a policeman, a prosecutor, a politician, or some other state actor (see Table 3). As a result, state actors play a key role in sowing public doubt about the innocence of those released from death row. Officials who were principally involved in securing convictions in death cases become central narrators when those convictions come undone.

In what follows we offer some examples of the ways news stories question innocence. For example, take the 1963 case of Freddie Pitts and Wilbert Lee. ${ }^{89}$ Their court-appointed attorney advised both men to plead guilty to the murders of two white gas station attendants, Grover Floyd Jr. and Jessie L. Burkett. Although there was no plea agreement with the prosecution, they hoped to avoid the death penalty. Nonetheless, an all-white jury sentenced both men to death.

The racial dimensions of the case were heightened by witness reports that Lee, who was indeed at the gas station earlier in the day, and some female acquaintances had argued with its owner after the women were denied use of a whites-only bathroom. The police and polygraph examiner, who had been forced out of the Air Force for eliciting a false confession in another case, questioned a witness,

86 In this and subsequent tables we focus on the subset of articles which contain some explanation or argument about why someone was released from death row.

87 See Michael Leo Owens \& Elizabeth Griffiths, Uneven Reparations for Wrongful Convictions: Examining the State Policies of Statutory Compensation Legislation, 75 Alb. L. Rev. 1283, 1317 (2011).

88 Just over $50 \%$ of death row exonerations result from the use of DNA or from some other means of establishing that the exonerees were "factually innocent." In other cases, the evidence obtained after trial showed that the state had not met its burden of proving legal guilt. See Description of Innocence Cases, Death Penalty Information Center, https://deathpenaltyinfo.org/policy-issues/innocence/description-of-innocence-cases (last visited Mar. 30, 2020).

89 Freddie Pitts, National Registry of Exonerationsl: Exonerations Before 1989, https://www.law.umich.edu/special/exoneration/Pages/casedetailpre1989. aspx? caseid=255 (last visited Jan. 26, 2020). 
Table 3. Who Questions Innocence? ${ }^{90}$

\begin{tabular}{|c|c|}
\hline Speaker & Percentage of Times Innocence is Questioned \\
\hline State & $177(68.3 \%)$ \\
\hline Advocate for Victim & $45(17.5 \%)$ \\
\hline Juror & $7(2.7 \%)$ \\
\hline Citizen & $26(10 \%)$ \\
\hline Newspaper & $4(1.5 \%)$ \\
\hline Total of Speakers who Questioned Innocence & 259 \\
\hline
\end{tabular}

nineteen-year-old Willie Mae Lee (no relation), for four days during which she denied any knowledge of the crime. However, after the discovery of Burkett and Floyd's bodies, she admitted to being an accomplice to the crime and implicated Lee and another man-Lambson Smith. When Smith's alibi proved unshakeable, she changed her story and implicated Freddie Pitts. The change in Lee's story was not revealed by the prosecution until well after the conviction of Pitts and Lee.

Both Pitts and Lee confessed under pressure, but soon recanted their confessions. Three years after their convictions, Curtis Adams Jr. confessed to the Burkett and Floyd murders. In 1968 Willie Mae Lee recanted her testimony. However, Pitts and Lee were not released until 1975.

Twenty-three years later they received $\$ 500,000$ each as compensation for their erroneous convictions. ${ }^{91}$ At that time, newspapers quoted Florida Rep. Jamey Westbrook who declared, "I think Mr. Pitts and Mr. Lee are guilty - there is no doubt about it." ${ }^{92}$ This is a concrete example of the directness with which news accounts sow doubt about an exoneree's innocence

In 2011, the state of Texas refused to compensate Clarence Brandley ${ }^{93}$ for his wrongful conviction and death sentence. ${ }^{94}$ Thirty-one years earlier, Brandley, while working as a janitor at a high school in Conroe, Texas, discovered the body of Cheryl Dee Ferguson in a loft above the school's auditorium. She had been raped and strangled. Brandley was with another janitor, Henry Peace, at the time. During his investigation of the crime, Texas Ranger Wesley Styles is reported to have said to the two men: "One of you is going to have to hang for this" and, turning to Brandley, added, "Since you're the n....r, you're elected."

90 The total here is larger than the 235 articles in which innocence is questioned because those articles may contain more than one instance in which that occurs.

91 John Kennedy, Pardoned Pair Lobby State for Their Cause: They Meet Legislators, Seeking Compensation, Fla. Sun-Sentinel, Apr. 15, 1998, at 10B. See also, Judge Okays \$1-Million Award to Men, St. Petersburg Times, May 23, 1998, at 1B.

92 Lucy Morgan, After 22 Years, Bill Passes on Claim of Ex-Death Row Inmates, ST. Petersburg Times, May 1, 1998, at 1B, 4B.

93 Alexandra Gross, Clarence Brandley, National Registry of Exonerations, https:// www.law.umich.edu/special/exoneration/Pages/casedetail.aspx?caseid=3044 (last visited Jan. 26, 2020).

94 Keri Blakinger, Wrongfully Convicted Ex-Death Row Inmate Clarence Brandley Dies, Months After DA Reopens Case, Hous. Chron. (Sept. 12, 2018), https://www. chron.com/news/houston-texas/article/Death-row-exoneree-Clarnece-Brandley-diesmonths-13220646.php. 
The other, all white, janitors at the school said that they had seen Brandley follow Ferguson to the loft. Semen recovered from her body was destroyed under suspicious circumstances, and no physical evidence was introduced at trial. Brandley's first trial resulted in a hung jury and a mistrial. During his retrial, in front of a second all-white jury, the prosecutor accused Brandley of being a necrophiliac. This time he was convicted and sentenced to death.

Less than a year after Brandley's conviction, his lawyers found out that the state had destroyed multiple pieces of potentially exculpatory evidence. It included the semen, Caucasian pubic hairs which matched neither the victim nor Brandley, and photographs which showed that Brandley was not wearing a belt on the day of the crime, which the prosecution had claimed was the murder weapon. Brandley came within six days of execution but was granted a stay because someone else confessed to Ferguson's murder. In addition, another janitor, John Sessum, recanted his statement implicating Brandley and instead said that another janitor, Gary Acreman, had committed the crime. Two other people claimed they had heard Acreman confess that he murdered Ferguson. In 1987 Brandley was granted a new trial, after which the prosecution dropped all charges against him.

News reports highlighted continuing doubts about Brandley's innocence. A story in the Dallas Morning News quoted one of the prosecutors in his case:

In the motion, Mr. Speers [a district attorney tasked with the Brandley case] argued that 'neither the facts, in any version, nor the law support the conclusion that Clarence Brandley was denied a fair trial. Clarence Brandley is guilty of this heinous crime, and nothing in this court's opinion even suggests that it believes otherwise. ${ }^{96}$

The article reports that the prosecution "conceded that it would be virtually impossible to retry Mr. Brandley because most of the physical evidence is missing and because key witnesses have recanted testimony." ${ }^{997}$ It concludes that Brandley's release will mean that a "vicious killer will walk free." has been released, but he is not exonerated. ${ }^{99}$

In the public life of exoneration, victims' families also play a role in questioning the innocence of those released from death row. For those families, exoneration takes away whatever comfort is provided by the conviction and sentencing of someone they believe to be responsible for their loved one's death. It is not surprising that some of them resist this conclusion, even as the evidence of the miscarriage of justice piles up in front of them.

The role of victim families is highlighted in news coverage of Rolando Cruz's case, one of the best-known exoneration cases. ${ }^{100}$ Cruz was convicted of the Jeanine Nicarico's murder in 1983 and was exonerated in 1995. Yet the victim's parents of

96 The Associated Press, DA Files Appeal in Brandley Case: Motion Seeks to Block Inmate's Release, Dall. Morning News, Dec. 29, 1989, at 14A.

$97 \quad I d$.

$98 \quad I d$.

99 Id.

100 Center on Wrongful Convictions, Rolando Cruz, National Registry of Exonerations, https://www.law.umich.edu/special/exoneration/Pages/casedetail.aspx?caseid=3140 (last visited Jan. 26, 2020). 
the victim remained so convinced of Cruz's guilt that they helped defend police officers and prosecutors who were indicted for "conspiring to deny justice" to Cruz in a lawsuit following his exoneration. ${ }^{101}$

The Nicaricos continued to believe in Cruz's guilt even after another man, Brian Dugan, confessed to the crime, and after recanted testimony and DNA evidence in the Cruz case became widely known. As the Chicago Sun-Times noted, "[The Nicaricos] also say they now accept that another man, Brian Dugan, was involved - as Dugan has reportedly confessed. But the Nicarico's say they believe Dugan acted with other defendants, even though a state police probe could find no link between them." 102

The inclusion of these kinds of statements in press coverage of exonerations means that instead of a celebration of innocence, that coverage feels like an unending tragedy for a suffering family. It gestures to the idea that there is a real victim, a real innocent, who it is not the exonerated. In this sense, the rhetorical patterns of the criminal justice system are reaffirmed and the harm done to exonerees by the state is minimized. When news stories question their innocence, exonerees are treated as if they were not a victim at all or as being less important than some other, more legitimate, victim.

\section{What Difference Does DNA MaKe?}

Table 4. Questioning Innocence in DNA Exonerations

\begin{tabular}{|c|c|}
\hline Innocence Questioned & \\
\hline DNA Case & $41(17.5 \%)$ \\
\hline Non-DNA Case & $194(82.5 \%)$ \\
\hline Total Number of Articles in Which Innocence is Questioned & 235 \\
\hline
\end{tabular}

Table 5. Who Questions Innocence?

\begin{tabular}{|c|c|c|}
\hline Speakers Questioning Innocence & DNA Cases & Non-DNA Cases \\
\hline State & $37(90.4 \%)$ & $129(66.5 \%)$ \\
\hline Advocate of Victim & $2(4.8 \%)$ & $32(16.5 \%)$ \\
\hline Juror & $1(2.4 \%)$ & $6(3.1 \%)$ \\
\hline Citizen & $1(2.4 \%)$ & $23(11.8 \%)$ \\
\hline Newspaper & $0(0.0 \%)$ & $4(2.1 \%)$ \\
\hline Total Number of Speakers Questioning Innocence & 41 & 194 \\
\hline
\end{tabular}

DNA is commonly thought to have been a difference maker in the national debate about capital punishment and in propelling the so called "new abolitionism," ${ }^{103}$ which focuses on the imperfections of the death penalty system rather than on

\footnotetext{
101 Thomas Frisbie, Nicaricos Keep up Courtroom Vigil. Couple Defends Indicted Cops, Ex-Prosecutors. Chi. Sun-Times, Jan. 26, 1997, at 24.

102 Id.

103 See Gould, supra note 23.
} 
its moral deficiencies. ${ }^{104}$ DNA is supposed to be able to tell us who was where, and who did what, and has revealed that many of the people on death row did not do what the state said they did. ${ }^{105}$ The very character of exoneration has been shaped by DNA. Some compensation statutes require that in order to qualify for compensation, the exoneration must have involved DNA evidence of some kind.

As Table 4 and 5 reveal, in a number of cases involving DNA, state actors continue to question innocence. They play a more prominent role in doing so in DNA cases than in exonerations where DNA played no role.

This questioning of innocence in DNA cases which result in exonerations is highlighted in the case of Robert Lee Miller who spent almost eleven years on death row in Oklahoma, convicted of the rape and murder of two elderly women. His conviction rested largely on forensic analysis showing that semen found at the scene matched Miller's blood type. However, DNA testing of that same sample later proved the semen belonged to an already-convicted rapist, Ronnie C. Lott, and not to Miller. As a result, Miller's conviction was overturned, and he was freed from death row.

However, as an article in the Daily Oklahoman reveals, prosecutors continued to insist that Miller was somehow involved in the crimes - " "The DNA in the body fluids found on the bed ruled out that he (Miller) was the rapist,' District Attorney Robert Macy said. 'Yet we believe he was there." ${ }^{106}$ Statements reported by the Tulsa World are even more jarring: "'It doesn't prove any innocent man was convicted,' Macy argued. 'All the evidence on which we convicted with is still valid." 107

At the time these statements were made, Lott had already been sentenced to twenty-five years for rapes of other elderly women which took place twenty blocks away from the scenes of Miller's supposed crimes. He had confessed and made no mention of a partner. Miller was an unquestionably innocent man, and yet his innocence was questioned repeatedly.

Another example of how little impact DNA can have on the trajectory of news coverage of exonerations is provided by Rudolph Holton's release from death row. Holton had an extensive criminal record, including convictions for armed robbery before he was sentenced to death in 1986 for murdering a seventeen-year-old prostitute in Tampa, Florida. He spent 16 years on death row for the crime before DNA proved that a hair found in the victim's mouth did not in fact match Holton's DNA.

A Tampa Bay Times article about Holton case quotes a member of the parole board who referred to DNA evidence as "a technicality," which "doesn't change what happened." 108 In a sense, he was correct. It did not change what had happened. Rudolph Holton was not, and never had been, actually guilty of the crime for which he was sent to death row. ${ }^{109}$

104 Id.

105 Id.

106 Diana Baldwin, Macy Investigating Man Freed in Murder, Окцаномам (Nov. 10, 1999), https://oklahoman.com/article/2674426/macy-investigating-man-freed-in-murder.

107 The Associated Press, DNA Evidence Clears Client, Lawyer Says, Tulsa World, Jan. 24, 1995, at N10.

108 Shannon Colavecchio-Van Sickler, Complicated Story Cuts an Early Release Short, TAMPA BAY TIMES (Jan. 20, 2006), https://www.tampabay.com/archive/2006/01/20/ complicated-story-cuts-an-early-release-short/.

109 Wire Reports, Digest, South Fla. Sun-Sentinel, Nov. 15, 2006 at 7B. 
Damon Thibodeaux ${ }^{110}$ was convicted of murdering fourteen-year-old Crystal (or Chrystal) Champagne, his step-cousin, in 1997, well-after DNA technology was widely available. After Champagne's partially-nude body was discovered, police interrogated Thibodeaux for nine hours during which he confessed. Yet there was no physical evidence tying him to the crime and the defendant recanted his confession as soon as he was allowed to eat and rest. Eventually, another man's DNA was discovered on the wire used to strangle Champagne and Thibodeaux was released. However, news coverage highlighted the District Attorney's continuing contention that, "Damon Thibodeaux cannot be excluded as a suspect." 111 Even where DNA evidence leads to exonerations such statements most often go unchallenged in press coverage.

\section{CONTINUING Adversariness}

Given the conventions of modern journalism, it is not surprising that news coverage of exoneration is characterized by the continuing of an adversarial structure between the state and the exonerated. In this structure, the defense and the prosecution have very different relationships to time. Exoneration is a past tense designation. The defense focuses on a truth it claims to have always known, that the convicted person was truly innocent. The state sees exoneration as, at best, about discovery of things that could not have been known in the past, circumstances that changed, facts that are now known but could not have been known before.

The adversarial structure of exoneration's news coverage is exemplified in the coverage of the Gabriel Solache case. ${ }^{12}$ Solache was convicted of murdering of Mariano and Jacinta Soto and kidnapping their two young children in Illinois. At the time, Solache, and nine others, lived with Adriana Meija, who left home on the day of the murder and returned with two children who were later identified as the kidnapped Sotos. After seeing a photo of the older boy on the news, her family pressured her to go to the police. Solache and Meija's husband accompanied Adriana to the police station. After a grueling interrogation, all of them confessed to the murders. However, suspicion ultimately focused on Adriana. Her husband was released, but Solache and another man were tried, convicted and sentenced.

In news coverage of Solache's and Reyes' release from death row, "First Assistant State's Attorney Eric Sussman said prosecutors still strongly believe Gabriel Solache and Arturo Reyes are guilty of the 1998 fatal stabbing of a couple in their Bucktown neighborhood home." "113 In contrast, the defense insisted: "Now

110 Alexandra Gross, Damon Thibodeaux, NATIONAL Registry of Exonerations (Sept. 28, 2012), https:/www.law.umich.edu/special/exoneration/Pages/casedetail. aspx? caseid $=4004$.

111 John Simerman, Paying the Price: Former Convicts Facing Pushback From State Over Innocence Compensation, New Orleans Advoc., May 29, 2016, at 1A.

112 Maurice Possley, Gabriel Solache, NAtional Registry of Exonerations (Jan. 3, 2018), https://www.law.umich.edu/special/exoneration/Pages/casedetail.aspx?caseid=5252.

113 Megan Crepeau, 2 Jailed in '98 Murders See Charges Dropped: State Cites Tainted Ex-Cop's Role in Confessions, CHI. TRIB. (Dec. 22, 2017), http://digitaledition. chicagotribune.com/tribune/article_popover.aspx?guid=5f6d1b27-0867-475c-95cded0553f436da. 
we have a judicial pronouncement of what we knew all along: Detective Guevara is a liar, he should not be believed and any case that rests upon his testimony should be thrown out." 114 In the news reports, the statements of prosecution and defense run in parallel. News coverage of exoneration conveys the continuing life of an adversarial understanding of facts and events and a continuing re-litigation of the story.

\section{Attributing Blame for Miscarriages of Justice}

Table 6. Attributing Blame for the Wrongful Convictions

\begin{tabular}{|c|c|}
\hline & Attribute Blame \\
\hline Yes & $334(32.2 \%)$ \\
\hline No & $702(67.8 \%)$ \\
\hline
\end{tabular}

As Table 6 reveals, in only one third of news stories about exoneration is blame attributed for the erroneous conviction. It often is difficult to point to a singular person, or department, more difficult perhaps to point to a rule or policy, and perhaps even more difficult to identify something that is fundamentally structurally wrong. In the absence of such attributions of blame, news coverage suggests that false convictions are, to borrow an idea from Judith Shklar, "misfortunes," accidents for which no one can or should be held accountable, rather than "injustices." 115

Table 7. Who Is Blamed for the Wrongful Conviction? ${ }^{116}$

\begin{tabular}{|c|c|}
\hline & Blamed \\
\hline Individual Actor & $221(59.4 \%)$ \\
\hline The State & $137(36.8 \%)$ \\
\hline The Exoneree & $1(3.8 \%)$ \\
\hline Total & 372 \\
\hline
\end{tabular}

When someone or something is blamed, blame is more often placed on an individual official within the criminal justice system than on the system itself. (See Table 7) Blaming "the state" in the general sense is as much a cry into the void, an expression of exasperation, as it is a genuine placement of blame.

Not surprisingly, exonerees or their advocates are most likely to point an accusing finger. (See Table 8) While police, prosecutors and other state officials are quoted more often than any other speakers in articles about exoneration, they were much less likely than those who have suffered a miscarriage of justice to find fault.

114 Id.

115 See Judith N. Shklar, The Faces of Injustice (1990).

116 The total number of people blamed is 372 . The number of articles in which someone is blamed is 334 because within a single article there may be multiple instances of blame. 
Table 8. Who Attributes Blame?

\begin{tabular}{|c|c|}
\hline Speakers doing the Blaming & \\
\hline State & $51(13.7 \%)$ \\
\hline Advocate of Victim & $4(1.1 \%)$ \\
\hline Juror & $1(0.3 \%)$ \\
\hline Citizen & $37(9.9 \%)$ \\
\hline Newspaper Reporter & $134(36 \%)$ \\
\hline Exoneree or His/Her Advocate & $145(39 \%)$ \\
\hline Total Number of Speakers Attributing Blame & 372 \\
\hline
\end{tabular}

Anthony Graves represents a typical case in which blame appears in news coverage of exonerations. Graves, the $138^{\text {th }}$ person exonerated from death row, ${ }^{117}$ was arrested when he was twenty-six years old for murdering a family of six people in Somerville, Texas. The district attorney's office offered no physical evidence or even a motive for the crime. Graves was convicted solely on the testimony of Robert Carter, who would himself later confess to the crime. Graves was on death row for 12 years until his conviction was overturned in 2006. However, the state continued to question his innocence and his release did not occur until $2010 .{ }^{118}$

In news coverage, Charles Sebesta, the prosecutor in the case, bears the brunt of the blame for Graves' conviction. Stories refer to him to as "obsessed with death," 119 "scheming," 120 "the man who almost single-handedly forced the Graves case through the courts,"121 and "rogue." 122 Sebesta did ultimately pay a price for his behavior in the Graves case (among others). He was disbarred but not prosecuted for his crime. ${ }^{123}$ However, Sebesta was a creature of a system, not an aberrational, exceptional evil. ${ }^{124}$ Nevertheless, news stories make no statements about the systemic issues that allowed or perhaps encouraged his behavior. ${ }^{125}$

117 Anthony Charles Graves, Infinite Hope: How Wrongful Conviction, Solitary Confinement, and 12 Years on Death Row Failed to Kill My Soul (2018).

118 Jon Schuppe, How Anthony Graves Went from Death Row to Overseeing the Houston Crime Lab, NBC News (June 27, 2015), https://www.nbcnews.com/news/us-news/howanthony-graves-went-death-row-overseeing-his-local-crime-n381891.

119 The Editorial Board, Obsessed with Death, Dall. Morning News, Jan. 30, 2011, at $\mathrm{P} 02$.

120 The Editorial Board, Life vs. Death, Dall. Morning News, Oct. 10, 2011, at A12.

121 The Editorial Board, An IOU on Justice, Dall. Morning News, May 3, 2011, at A18.

122 White Mckinney, State Bar Investigation into Death Penalty Case Is a Conflict of Interest, Dall. Morning News, July 14, 2014.

123 Amanda Holpuch, Texas Prosecutor Officially Disbarred for Sending Innocent Man to Death Row, Guardian (Feb. 9, 2016), https://www.theguardian.com/us-news/2016/ $\mathrm{feb} / 09 /$ texas-prosecutor-charles-sebesta-disbarred-anthony-graves-innocent-death-row.

124 For an analysis of the systemic nature of prosecutorial misconduct in Texas death cases, see Guy Goldberg \& Gena Bunn, Balancing Fairness \& Finality: A Comprehensive Review of the Texas Death Penalty, 5 Tex. Rev. L \& Pol. 49, 109 (2000).

125 Brian Rogers, Freed Death Row Inmate Goes After His Prosecutor Wrongfully Convicted Texan, Lawmakers Urge State Bar to Take Action Against Ex-DA, Hous. Chron. (Jan. 21, 2014), https://www.houstonchronicle.com/news/houston-texas/houston/article/ Freed-death-row-inmate-takes-action-against-5160551.php. 
Frank Lee Smith died of cancer while on Florida's Death Row, but, on December 15,2000 , he was posthumously exonerated by DNA which conclusively excluded him from guilt. ${ }^{126}$ Smith had been convicted of a 1985 home invasion, rape and murder of an eight-year-old girl in Broward County, Florida. ${ }^{127}$ Witnesses, a neighbor and the victim's mother, said they saw an unidentified black man, approximately six feet tall, around thirty years old, near the scene of the crime. Smith was arrested based on a composite sketch from the description that they provided.

During the appeals process, one witness recanted her identification of Smith, and Smith's defense team requested DNA testing of semen found on the victim. However, Smith died before those requests were granted. However, his case prompted Governor Jeb Bush to appoint a special prosecutor specifically to look into what went wrong. Newspapers blamed Captain Richard Scheff who was accused of lying to convict Smith. ${ }^{128}$ However, the special prosecutor who investigated Scheff decided that there was insufficient evidence to show he lied. ${ }^{129}$

In its coverage the Tampa Bay Times characterized the Smith case as an example of systemic failure rather than individual fault. Pulitzer Prize winning journalist Sydney P. Freedberg flatly notes that, "they got it all wrong. Florida locked up the wrong man for 14 years and left the real killer free - to commit other grievous crimes." 130 An editorial in the Tampa Bay Times remarks, "It's bad enough when the system sends an innocent man to prison by accident. It's intolerable if it does so by design." 131 It goes on to say that, "the advent of DNA testing has shown how fallible the system can be. Now the challenge is to make it better." 132 The Sun-Sentinel reported that "Smith's case, opponents of the death penalty say, underscores the flaws in the system that may lead to the execution of the innocent." 133 Such an attribution offers no insight into what about the "system" needs change. In Smith's case blame is placed on no one and nothing in particular.

126 Glossary, NATIONAL Registry of ExONERATIONS, https://www.law.umich.edu/special/ exoneration/Pages/glossary.aspx (last visited Mar. 30, 2020).

127 Frankie Lee Smith, National Registry of Exonerations, https:/www.law.umich.edu/ special/exoneration/Pages/casedetail.aspx?caseid=3644 (last visited Jan. 18, 2020).

128 See, e.g., Ardy Friedberg, Sheriff Supports Inquiry - Captain Is Accused of Lying in Testimony, Fla. Sun Sentinel, Mar. 2, 2001, at 1B; John Holland \& Shannon O’Boye, Sheriff's Captain Accused of Lying - Officer Who Helped Send an Innocent Man to Death Row is Target of Inquiry by Special Prosecutor, Fla. Sun Sentinel, Mar. 1, 2001, at 1A.

129 Paula McMahon, BSO Settles Lawsuit with Family of an Exonerated by DNA, FLA. SunSENTinel (July 21, 2013), http://articles.sun-sentinel.com/2013-07-21/news/fl-franklee-smith-dna-settled-20130721_1_virginia-smith-civil-lawsuit-scheff-and-amabile.

130 Sydney P. Freedberg, He Didn't Do It, Tampa Bay Times, Jan. 7, 2001, at 1 A.

131 The Editorial Board, Following Trail of Injustice, TAmpA BAY Times, Mar. 6, 2001, at 17A. See also The Editorial Board, Policing Prosecutors. TAmpa Bay Times, July 12, 2003, at 16A; Frank Lee Smith, InNOCENCE Project, https://www.innocenceproject.org/ cases/frank-lee-smith/ (last visited (Mar. 30, 2020).

132 The Editorial Board, Following Trail of Injustice, TAMPA BAY Times, Mar. 6, 2001, at $17 \mathrm{~A}$.

133 Damian P. Gregory, Activists Urge End to Death Penalty, Sun-Sentinel, Dec. 19, 2000, at $4 \mathrm{~B}$. 


\section{CONCLUSION}

To say that someone has been exonerated is to name a singular truth, but newspapers conventionally present only different interpretations of that reality. Newspapers regularly communicate doubt about the connection between exoneration and actual innocence. They do so by avoiding the language of exoneration entirely and/or by conveying continuing adversarial perspectives on the meaning of miscarriages of justice in death cases.

It is rare that newspapers help their readers understand what forces produce such miscarriages of justice. Moreover, they generally do not focus on the traumatic experience of life on death row, the fear of imminent death, the isolation, the loss of relationships, the health battles, the psychological damage, and on the difficulty of adjusting to life on the outside. And, as we have shown above, they often avoid calling the exonerated person what they are: innocent.

In the end, our research suggests that the traction the recognition of miscarriages of justice has had in changing the national conversation around the death penalty has been gained in spite of, not because of, the way newspapers cover such events. 
